\title{
Effects of the mycorrhizal fungus Glomus intraradices on uranium uptake and accumulation by Medicago truncatula $\mathrm{L}$. from uranium-contaminated soil
}

\author{
Baodong Chen ${ }^{1}$, Iver Jakobsen ${ }^{2}$, Per Roos ${ }^{3}$, and Yong-Guan Zhu ${ }^{1,4}$ \\ ${ }^{1}$ Department of Soil Environmental Science, Research Center for Eco-Environmental Sciences, Chinese \\ Academy of Sciences, 18 Shang Qing Road, 100085, Beijing China. ${ }^{2}$ Biosystems Department, Riso National \\ Laboratory, DK-4000, Roskilde, Denmark. ${ }^{3}$ Radiation Research Department, Riso National Laboratory, \\ DK-4000, Roskilde, Denmark. ${ }^{4}$ Corresponding author*
}

Received 1 January 2005. Accepted in revised form 22 February 2005

Key words: arbuscular mycorrhiza, Glomus intraradices, Medicago truncatula, phytoremediation, uranium (U)

\begin{abstract}
Phytostabilization strategies may be suitable to reduce the dispersion of uranium (U) and the overall environmental risks of U-contaminated soils. The role of Glomus intraradices, an arbuscular mycorrhizal (AM) fungus, in such phytostabilization of $U$ was investigated with a compartmented plant cultivation system facilitating the specific measurement of $U$ uptake by roots, AM roots and extraradical hyphae of AM fungi and the measurement of $\mathrm{U}$ partitioning between root and shoot. A soil-filled plastic pot constituted the main root compartment $\left(\mathrm{C}_{\mathrm{A}}\right)$ which contained a plastic vial filled with $\mathrm{U}$-contaminated soil amended with 0,50 or $200 \mathrm{mg} \mathrm{K \textrm {K } _ { 2 }} \mathrm{PO}_{4}-\mathrm{P} \mathrm{kg}^{-1}$ soil $\left(\mathrm{C}_{\mathrm{B}}\right)$. The vial was sealed by coarse or fine nylon mesh, permitting the penetration of both roots and hyphae or of just hyphae. Medicago truncatula plants grown in $\mathrm{C}_{\mathrm{A}}$ were inoculated with $G$. intraradices or remained uninoculated. Dry weight of shoots and roots in $\mathrm{C}_{\mathrm{A}}$ was significantly increased by $G$. intraradices, but was unaffected by mesh size or by $\mathrm{P}$ application in $\mathrm{C}_{\mathrm{B}}$. The $\mathrm{P}$ amendments decreased root colonization in $\mathrm{C}_{\mathrm{B}}$, and increased $\mathrm{P}$ content and dry weight of those roots. Glomus intraradices increased root $\mathrm{U}$ concentration and content in $\mathrm{C}_{\mathrm{A}}$, but decreased shoot $\mathrm{U}$ concentrations. Root $\mathrm{U}$ concentrations and contents were significantly higher when only hyphae could access $\mathrm{U}$ inside $\mathrm{C}_{\mathrm{B}}$ than when roots could also directly access this $\mathrm{U}$ pool. The proportion of plant $\mathrm{U}$ content partitioned to shoots was decreased by root exclusion from $C_{B}$ and by mycorrhizas (M) in the order: no $M$, roots in $C_{B}>$ no $M$, no roots in $C_{B}>M$, roots in $C_{B}>M$, no roots in $C_{B}$. Such mycorrhiza-induced retention of $U$ in plant roots may contribute to the phytostabilization of $U$ contaminated environments.
\end{abstract}

\section{Introduction}

Uranium (U) is one of the most toxic radionuclides and can disperse in environments due to the exploration and utilization of nuclear energy (Ebbs et al., 1998; Xu et al., 2002). U in environments endangers both human and animal health

\footnotetext{
* FAX No: 8610-62936940; E-mail: ygzhu@mail.rcees.ac.cn
}

(Fellows et al., 1998), and proper management of U-contaminated environments has become an urgent need. Traditional chemical and physical strategies turned out to be costly and have produced uncertain results and alternative pollution control techniques have been considered (Francis and Dodge, 1998; Zhu and Shaw, 2000). Phytoremediation has been widely accepted as an economic, environment-friendly and efficient 
approach for management of soils contaminated by heavy metals or radionuclides (Dushenkov, 2003; Shahandeh et al., 2001; Zhu and Shaw, 2000). Phytoextraction of $U$ was induced by amending soil with organic acids (Huang et al. 1998), but ultimate remediation or cleaning up of contaminants is in most cases impractical for economic and periodical reasons, especially on heavily contaminated sites or mine tailings. Phytostabilization is an alternative strategy, which could prevent $\mathrm{U}$ dispersion in environments. The feasibility of $\mathrm{U}$ phytostabilization is supported by the fact that only a few hyperaccumulating plant species have been identified (Whiting et al., 2004), whereas many plants can accumulate $U$ in their roots despite large variation in $\mathrm{U}$ uptake capability (Sheppard and Thibault, 1984; Saric et al., 1995).

$\mathrm{U}$ speciation is closely related to soil properties (especially pH) (Ebbs et al., 1998; Langmuir, 1978; Mortvedt, 1994;) and is one of the key factors influencing $\mathrm{U}$ uptake by plants. $\mathrm{U}$ is most mobile as U(VI) (Campbell and Biddle, 1977). $\mathrm{U}(\mathrm{VI})$ exists in solution predominantly as $\mathrm{UO}_{2}{ }^{2+}$ and as soluble carbonate complexes (Ciavatta et al., 1981; Duff and Amrhein, 1996; Grenthe et al., 1992; Langmuir, 1978). Between pH 4.0 and 7.5 , the $\mathrm{pH}$ range of most soils, $\mathrm{U}(\mathrm{VI})$ exists primarily in hydrolyzed forms (Meinrath et al., 1996). Plants take up $U$ from the readily exchangeable and soluble fractions of the soil. However, according to previous work, negligible amount of $\mathrm{U}(\mathrm{VI})$ remain in the soluble and exchangeable forms over any significant time, thereby limiting the amount available for plant uptake and subsequent phytoremediation (Bunzl et al., 1995; Sheppard and Thibault, 1992). In addition, plant-associated microorganisms, including mycorrhizal fungi, may have significant effects on U uptake (Rufyikiri et al., 2002, 2003, 2004b). Arbuscular mycorrhizae (AM) are ubiquitous symbiotic associations between higher plants and soil fungi (Smith and Read, 1997) and their extraradical mycelium form bridges between plant roots and soil, and mediate the transfer of various elements into plants. It has been demonstrated that mycorrhizas could protect plants grown in metal-contaminated soils by enhancing metal retention in roots and reducing metal partitioning to shoots (Leyval et al., 2002). There is direct evidence for the strong binding capacity of fungal mycelium to heavy metals, such as $\mathrm{Zn}$ and Cd (Chen et al., 2001; Joner et al., 2000). Therefore, AM can possibly be used for the stabilization of metals in soil environments, revegetation and ecological restoration of metal-polluted sites.

As $\mathrm{U}$ behaviour in soil is similar to heavy metals such as $\mathrm{Pb}$, it can be deduced that mycorrhizal fungi should enhance the immobilization of $U$ by roots. It was recently shown that the extraradical AM fungal mycelium took up and translocated $\mathrm{U}$ towards root in in vitro culture system (Rufyikiri et al., 2002), and hyphae were more efficient in $\mathrm{U}$ translocation compared with roots (Rufyikiri et al., 2004a). Soluble uranyl cations or uranyl-sulphate species that are stable under acidic conditions were translocated to a higher extent to roots through fungal tissues, while phosphate and hydroxyl species dominating under acidic to near neutral conditions or carbonate species dominating under alkaline conditions were rather immobilized by hyphal structures (Rufyikiri et al., 2002). However, U transfer from roots to shoots could not be quantified by this model system and studies of $U$ uptake and accumulation by intact plants are required in order to elucidate the potential role of AM in management of $U$ contaminated environments. An in vivo study was therefore carried out to compare $\mathrm{U}$ uptake by non-mycorrhizal roots, mycorrhizal roots and extraradical hyphae and $U$ redistribution in medic plants using a compartmented cultivation system. The study aimed to investigate mycorrhizal effects on $\mathrm{U}$ translocation in the plant-soil continuum, and to evaluate the potential role of AM fungi in phytoremediation of $\mathrm{U}$ contaminated soil. Different $\mathrm{P}$ application levels were included to investigate their interactions with plant accumulation of $U$.

\section{Materials and methods}

\section{Host plant and AM fungi}

Seeds of medic plants (Medicago trunctula $\mathrm{L}$. cv Jemalong) were pre-germinated in aerated distilled water for $36 \mathrm{~h}$. The AMF Glomus intraradices Schenck and Smith (BEG 87) was propagated on subterranean clover (Trifolium subterraneum L.) in 
sand-soil mixture for 10 weeks and the inoculum was a mixture of growth medium, fungal spores, mycelium and colonized root fragments.

\section{Compartmented cultivation system}

A plastic pot constituted the main root compartment $\left(\mathrm{C}_{\mathrm{A}}\right)$, which also contained a $50 \mathrm{~mL}$ plastic vial $\left(C_{B}\right)$ filled with U-contaminated soil. The vial was sealed by $650 \mu \mathrm{m}$ or $25 \mu \mathrm{m}$ nylon net, which permitted the penetration of both roots and hyphae or of just hyphae, respectively, into the contaminated soil (Figure1).

\section{Cultivation media}

The growth medium filled in $\mathrm{C}_{\mathrm{A}}$ was a $1: 1(\mathrm{w} / \mathrm{w})$ mixture of sand and soil, which was partially sterilized (10 kGy, $10 \mathrm{MeV}$ electron beam). Basal nutrients without P (Pearson and Jakobsen, 1993) were added to the mixture. The soil-sand mixture (subsequently referred to as soil) had a $\mathrm{pH}$ of 6.7 (1: 2.5 soil to water) and a final extractable $\mathrm{P}$ content of $5.9 \mathrm{mg} \mathrm{kg}^{-1}$, using the method of Olsen et al. (1954), detailed information of the soil properties was reported by Jakobsen and Nielsen, 1983). U contaminated soil (SCK U-A3) filled in $\mathrm{C}_{\mathrm{B}}$ was collected from the storage of $\mathrm{U}$ tailings at Schlema $U$ mine site, Germany and passed through a $2 \mathrm{~mm}$ sieve. The U-mining debris originates from carbonaceceous micaceous shist and has apparent density of $1.62 \mathrm{~g} \mathrm{~cm}^{-3}, \mathrm{pH}$ of 7.3 (1: 2.5 in water), extractable $\mathrm{P}$ of $1.3 \mathrm{mg} \mathrm{kg}^{-1}$, total $\mathrm{U}$ of $53 \mathrm{mg} \mathrm{kg}{ }^{-1}$, organic matter content of $3.7 \%$ and cation exchange capacity of $5.7 \mathrm{cmol} \mathrm{kg}^{-1}$.

\section{Experiments}

Nutrient-amended growth medium for each pot $\left(\mathrm{C}_{\mathrm{A}}\right)$ was mixed with either $70 \mathrm{~g}$ of the $G$. intraradices inoculum or the equivalent amount of the soil-sand mixture was carefully mixed into the soil to obtain the inoculation treatments and the noninoculation controls. $\mathrm{KH}_{2} \mathrm{PO}_{4}-\mathrm{P}$ was mixed into the SCK soil to obtain 0,50 or $200 \mathrm{mg} \mathrm{P} \mathrm{kg}^{-1}$. The $\mathrm{C}_{\mathrm{B}}$ vials received $50 \mathrm{~g}$ amended $\mathrm{SCK}$ soil, which was then covered by $20 \mathrm{~g}$ soil-sand mixture as a buffering soil layer. The combination of two inoculation treatments, three $\mathrm{P}$ levels in $\mathrm{C}_{\mathrm{B}}$ and two nylon mesh sizes resulted in 12 treatments. Each treatment had four replicates and the 48 pots were set-up in a complete randomized block design. Medic seeds were selected for uniformity before sowing, and six pre-germinated seeds were sown in each pot. Three days after emergence seedlings were thinned to three per pot. The experiment was conducted in a controlled environment chamber with a $16 \mathrm{~h}-21{ }^{\circ} \mathrm{C}$ day and $8 \mathrm{~h}-16^{\circ} \mathrm{C}$ night regime. Osram daylight lamps provided $550 \mu \mathrm{E} \mathrm{m}^{-2} \mathrm{~s}^{-1}$ PAR (400-700 nm). De-ionized water was added as required to maintain moisture content at $55 \%$ of water holding capacity by regular weighing. A solution of $\mathrm{NH}_{4} \mathrm{NO}_{3}$ was added to the pots 32,37

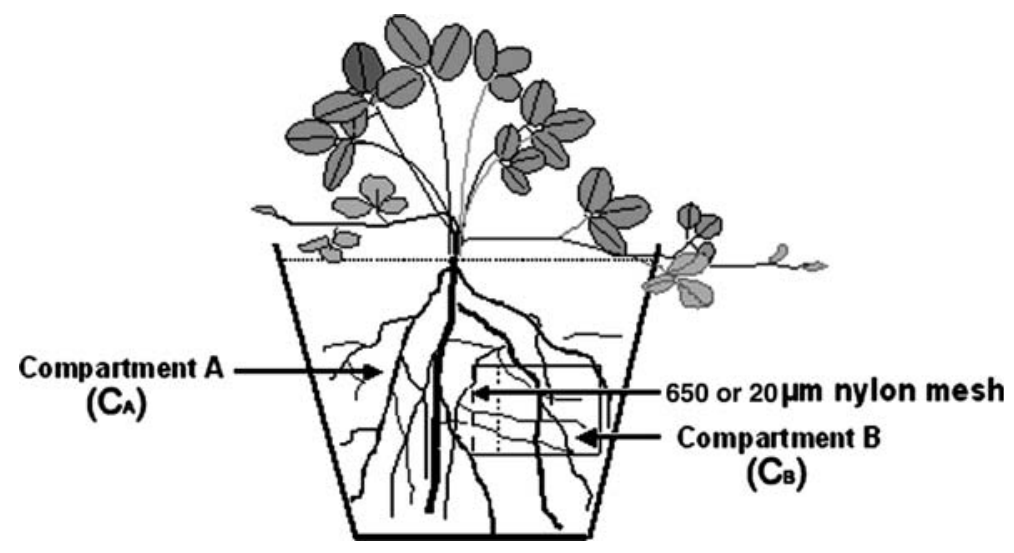

Figure 1. Diagram of the compartmented cultivation system. Coarse ( $25 \mu \mathrm{m}$ mesh size) or fine ( $37 \mu \mathrm{m}$ mesh size) nylon net was used to separate the cultivation system into two compartments: compartment A (plastic pot, the main compartment) for plant growth, and compartment B (a small container inside plastic pot) for hyphae, roots or mycorrhizal roots development depending on inoculation treatments and nylon net applied. 
Table 1. Mycorrhizal colonization rates and hyphal length density of medic plants in association with G. intraradices as influenced by different compartmentation and $\mathrm{P}$ addition treatments

\begin{tabular}{|c|c|c|c|c|c|c|}
\hline \multirow{2}{*}{$\begin{array}{l}\text { Inoculation } \\
\text { treatment }\end{array}$} & \multirow{2}{*}{$\begin{array}{l}\text { Type of } \\
\text { nylon mesh }\end{array}$} & \multirow{2}{*}{$\begin{array}{l}\mathrm{P} \text { addition levels in } \\
\text { Comp. } \mathrm{B}\left(\mathrm{mg} \mathrm{kg}^{-1}\right)\end{array}$} & \multicolumn{2}{|c|}{ Root colonization (\%) } & \multicolumn{2}{|c|}{ Hyphal length density $\left(\mathrm{mg}^{-1}\right)$} \\
\hline & & & Compartment A & Compartment B & Compartment A & Compartment B \\
\hline \multirow[t]{6}{*}{ Non-inoculated } & Coarse mesh & 0 & 0 & 0 & 5.5 & 0.7 \\
\hline & & 50 & 0 & 0 & 5.6 & 0.8 \\
\hline & & 200 & 0 & 0 & 5.6 & 0.7 \\
\hline & Fine mesh & 0 & 0 & - & 4.8 & 0.5 \\
\hline & & 50 & 0 & - & 4.8 & 0.9 \\
\hline & & 200 & 0 & - & 5.7 & 0.4 \\
\hline \multirow[t]{6}{*}{ Inoculated } & Coarse mesh & 0 & 77 & 87 & 14.5 & 8.6 \\
\hline & & 50 & 78 & 74 & 13.6 & 8.7 \\
\hline & & 200 & 75 & 63 & 12.4 & 7.5 \\
\hline & Fine mesh & 0 & 84 & - & 13.3 & 10.1 \\
\hline & & 50 & 84 & - & 11.4 & 10.4 \\
\hline & & 200 & 81 & - & 11.3 & 13.7 \\
\hline \multicolumn{7}{|l|}{ Significance $^{\mathrm{a}}$ of } \\
\hline Inoculation (I) & & & $* * *$ & $* * *$ & $* * *$ & $* * *$ \\
\hline Mesh type (M) & & & $* * *$ & - & $*$ & $* *$ \\
\hline $\mathrm{P}$ addition $(\mathrm{P})$ & & & NS & $* *$ & NS & NS \\
\hline $\mathrm{I} \times \mathrm{M}$ & & & $* * *$ & - & NS & $* * *$ \\
\hline $\mathrm{I} \times \mathrm{P}$ & & & NS & $* *$ & NS & NS \\
\hline $\mathrm{M} \times \mathrm{P}$ & & & NS & - & NS & NS \\
\hline $\mathrm{I} \times \mathrm{M} \times \mathrm{P}$ & & & NS & - & NS & $*$ \\
\hline
\end{tabular}

${ }^{a}$ By analysis of variance; $* * * P<0.001 ; * * P<0.01 ; * P<0.05 ;$ NS, not significant.

and 42 days after sowing to provide a total of $120 \mathrm{mg} \mathrm{N}$ per pot.

\section{Harvest and analysis}

The experiment was harvested 7 weeks after seedling emergence. Shoots were carefully cut off from the stem base and soil samples (about $20 \mathrm{~g}$ fresh weight) were collected for determination of hyphal length density before washing out roots. Roots growing into $C_{B}$ equipped with coarse nylon mesh were excised along the mesh and all $\mathrm{C}_{\mathrm{B}}$ compartments were removed from pots and stored frozen for later quantification of roots and hyphae. Roots in $\mathrm{C}_{\mathrm{A}}$ were washed with tap water and all plant samples were carefully washed with de-ionised water to remove adhering soil particles. Sub-samples of fresh roots were collected for the determination of AM colonization. Dry weights of shoots and roots were determined after oven drying at $70{ }^{\circ} \mathrm{C}$ for $48 \mathrm{~h}$. Oven-dried sub-samples were milled and digested in mixture of $\mathrm{HNO}_{3}$ and $\mathrm{HClO}_{4}(4: 1 \mathrm{v} / \mathrm{v})$ at $225^{\circ} \mathrm{C}$. Along with the samples four procedure blanks were run.
The dissolved samples were analysed for uranium $\left({ }^{238} \mathrm{U}\right)$ on a High Resolution - Inductively Coupled Plasma-Mass Spectrometry (HR-ICP-MS, PlasmaTrace 2, Micromass) without any radiochemical treatment. The uranium isotope ${ }^{233} \mathrm{U}$ was used as an internal standard. Preliminary study showed that the $U$ signal in the plant material was well above background and typical procedure blank levels were two to three orders of magnitude lower than what was found in the plant materials. Phosphorus in plant samples was determined by Inductively Coupled Plasma-Optical Emission Spectroscopy (ICP-OES, Vista axial, Varian).

Sub-samples of fresh roots were cleared in $10 \% \mathrm{KOH}$ and stained with Trypan blue by a modification of the procedure of Phillips and Hayman (1970), omitting phenol from solutions and $\mathrm{HCl}$ from the rinse. Percentage root colonization and root length were determined by the grid line intersect method (Giovannetti and Mosse, 1980). External hyphae were extracted from soil samples using a modified membrane filter technique (Jakobsen et al., 1992). 


\section{Statistical analysis}

Root data from $C_{B}$ were analysed by two-way ANOVA to compare mycorrhizal status and $\mathrm{P}$ application levels. All other experimental data were analysed by three-way ANOVA to compare mycorrhizal status, compartmentation pattern and $\mathrm{P}$ application levels using GenStat for $\mathrm{PC} /$ Windows 6.1 (GenStat Committee, 2002).

\section{Results}

Colonization of roots and soil by $\mathrm{G}$. intraradices

Roots of inoculated plants were extensively colonized by $G$. intraradices while non-inoculated controls remained non-mycorrhizal (Table 1). For inoculated plants the colonization of roots in $\mathrm{C}_{\mathrm{A}}$ was higher when $\mathrm{C}_{\mathrm{B}}$ was sealed by the $25 \mu \mathrm{m}$ nylon mesh than when $C_{B}$ was sealed by the $650 \mu \mathrm{m}$ nylon mesh $(P<0.001)$. Colonization of
$\mathrm{C}_{\mathrm{B}}$ roots decreased with increasing $\mathrm{P}$ application $(P<0.001)$.

The size of mesh sealing $C_{B}$ had different effects on hyphal length density in $\mathrm{C}_{\mathrm{A}}$ and $\mathrm{C}_{\mathrm{B}}$ : the coarse mesh resulted in the highest length densities in $\mathrm{C}_{\mathrm{A}}(P<0.05)$ while the fine mesh resulted in the highest length densities in $C_{B}$ $(P<0.01)$ (Table 1). On the other hand, hyphal growth was unaffected by $\mathrm{P}$ levels in $\mathrm{C}_{\mathrm{B}}$. Some hyphae were also present in non-inoculated pots, but at lower densities in $\mathrm{C}_{\mathrm{B}}$ than in $\mathrm{C}_{\mathrm{A}}$ soil. These hyphae were probably dead or saprophytic and were assumed to be also present in the inoculated treatments.

\section{Plant growth}

Dry weights of both shoots and $\mathrm{C}_{\mathrm{A}}$ roots were significantly increased by inoculation with $G$. intraradices $(P<0.001)$, but were unaffected either by compartmentation or by $\mathrm{P}$ application (Figure 2). However, dry weights of $C_{B}$ roots

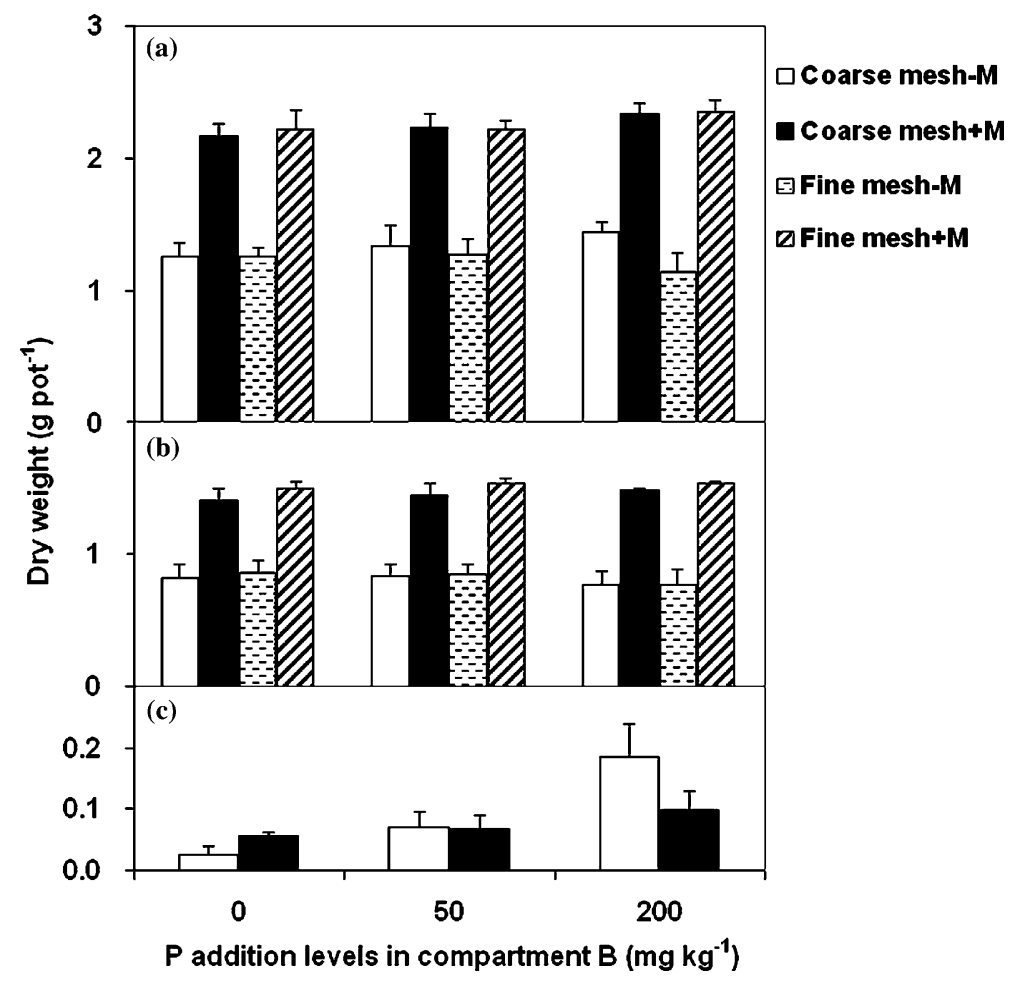

Figure 2. Dry weight of shoots (a), roots in compartment A (b) and compartment B (c) of medic plants under different compartmentation and $\mathrm{P}$ application treatments. $-\mathrm{M}$ and $+\mathrm{M}$ represent non-inoculation treatment and inoculation with mycorrhizal fungus $G$. intraradices. By analysis of variance, inoculation was highly significant $(P<0.001)$ for both shoot and root in compartment A. Interaction between inoculation and mesh size was significant $(P<0.05)$ for shoot. Phosphorus $(P<0.001)$ and interaction of $\mathrm{P}$ application with inoculation $(P<0.01)$ was highly significant for root in compartment $\mathrm{B}$. 
increased with increasing $\mathrm{P}$ levels $(P<0.001)$, and this response was larger in non-inoculated controls than in inoculated treatments.

\section{Plant phosphorus nutrition}

$\mathrm{P}$ concentrations in plant shoots and in $\mathrm{C}_{\mathrm{A}}$ roots were affected by inoculation only $(P<0.001)$ (Table 2), while $P$ concentrations in $C_{B}$ roots were increased not only by inoculation with G. intraradices $(P<0.01)$, but also by $\mathrm{P}$ applications $(P<0.01)$.

Mycorrhizal colonization increased plant $\mathrm{P}$ content in shoots and in $\mathrm{C}_{\mathrm{A}}$ roots $(P<0.001)$ (Figure 3). Shoot $\mathrm{P}$ content also increased with increasing $\mathrm{P}$ levels in $\mathrm{C}_{\mathrm{B}}(P<0.05)$ while $\mathrm{P}$ content in $\mathrm{C}_{\mathrm{A}}$ roots was higher with the fine than with the coarse mesh sealing $\mathrm{C}_{\mathrm{B}}$ $(P<0.001)$, and the $\mathrm{P}$ content in $\mathrm{C}_{\mathrm{B}}$ roots increased with increasing $\mathrm{P}$ application $(P<0.001)$ but was unaffected by mycorrhizal inoculation.

\section{Uranium uptake and partitioning}

Shoot U concentrations were generally lower in inoculated plants than in non-inoculated controls $(P<0.001)$, and also lower when $\mathrm{C}_{\mathrm{B}}$ was sealed by a fine instead of a coarse mesh $(P<0.001)$ (Table 2). In contrast, root $U$ concentrations were higher in inoculated plants than in controls $(P<0.001)$, and higher with a coarse than with a fine mesh $(P<0.01)$. Root $\mathrm{U}$ concentrations in $\mathrm{C}_{\mathrm{B}}$ were 10-50-fold the concentrations in $\mathrm{C}_{\mathrm{A}}$ roots, but were unaffected by inoculation or $\mathrm{P}$ applications (Table 2).

Shoot $\mathrm{U}$ content was increased by root penetration into the $U$ contaminated $C_{B}$ soil $(P<0.001)$ (Figure $4 \mathrm{a})$ and treatment interactions were complex among $\mathrm{P}$ application, inoculation and compartmentation $(P<0.05)$ : With the $650 \mu \mathrm{m}$ mesh sealing $\mathrm{C}_{\mathrm{B}}$, shoot $\mathrm{U}$ contents was increased by both $\mathrm{P}$ application in $\mathrm{C}_{\mathrm{B}}$ and mycorrhiza, while when the $25 \mu \mathrm{m}$ mesh was used, mycorrhiza decreased shoot $\mathrm{U}$ contents.

Table 2. $\mathrm{P}$ and ${ }^{238} \mathrm{U}$ concentrations in medic plants in association with $G$. intraradices as influenced by different compartmentation and $\mathrm{P}$ addition treatments

\begin{tabular}{|c|c|c|c|c|c|c|c|c|}
\hline \multirow[t]{2}{*}{$\begin{array}{l}\text { Inoculation } \\
\text { treatment }\end{array}$} & \multirow[t]{2}{*}{$\begin{array}{l}\text { Type of } \\
\text { nylon mesh }\end{array}$} & \multirow{2}{*}{$\begin{array}{l}\mathrm{P} \text { addition levels } \\
\text { in Comp. B } \\
\left(\mathrm{mg} \mathrm{kg}^{-1}\right)\end{array}$} & \multirow{2}{*}{$\begin{array}{l}\text { Shoot P } \\
\text { concentration } \\
\left(\mathrm{mg} \mathrm{g}^{-1}\right)\end{array}$} & \multicolumn{2}{|c|}{$\begin{array}{l}\text { Root P concentra- } \\
\text { tion }\left(\mathrm{mg} \mathrm{g}^{-1}\right)\end{array}$} & \multirow{2}{*}{$\begin{array}{l}\text { Shoot U } \\
\text { concentration } \\
\left(\mathrm{ng} \mathrm{kg}^{-1}\right)\end{array}$} & \multicolumn{2}{|c|}{$\begin{array}{l}\text { Root U concentra- } \\
\text { tion }\left(\mathrm{ng} \mathrm{kg}^{-1}\right)\end{array}$} \\
\hline & & & & Comp. A & Comp. B & & Comp. A & Comp. B \\
\hline \multirow[t]{6}{*}{ Non-inoculated } & \multirow[t]{3}{*}{ Coarse mesh } & 0 & 0.83 & 1.03 & 0.53 & 10.63 & 123 & 5972 \\
\hline & & 50 & 0.78 & 0.91 & 0.87 & 7.62 & 122 & 5948 \\
\hline & & 200 & 0.90 & 1.07 & 1.28 & 12.87 & 152 & 1798 \\
\hline & \multirow[t]{3}{*}{ Fine mesh } & 0 & 0.81 & 0.97 & - & 8.42 & 142 & - \\
\hline & & 50 & 0.78 & 1.08 & - & 11.64 & 164 & - \\
\hline & & 200 & 0.79 & 0.98 & - & 5.18 & 130 & - \\
\hline \multirow[t]{6}{*}{ Inoculated } & \multirow[t]{3}{*}{ Coarse mesh } & 0 & 0.89 & 1.46 & 0.98 & 7.09 & 182 & 5218 \\
\hline & & 50 & 0.92 & 1.46 & 1.80 & 8.25 & 141 & 4049 \\
\hline & & 200 & 0.97 & 1.46 & 1.59 & 7.58 & 188 & 6023 \\
\hline & \multirow[t]{3}{*}{ Fine mesh } & 0 & 0.90 & 1.44 & - & 3.82 & 203 & - \\
\hline & & 50 & 0.98 & 1.60 & - & 4.29 & 202 & - \\
\hline & & 200 & 0.98 & 1.63 & - & 3.33 & 183 & - \\
\hline \multicolumn{9}{|l|}{ Significance $^{\mathrm{a}}$ of } \\
\hline Inoculation (I) & & & $* * *$ & $* * *$ & $* *$ & $* * *$ & $* * *$ & NS \\
\hline Mesh type (M) & & & NS & NS & - & $* * *$ & $* *$ & - \\
\hline $\mathrm{P}$ addition $(\mathrm{P})$ & & & NS & NS & $* *$ & NS & NS & NS \\
\hline $\mathrm{I} \times \mathrm{M}$ & & & NS & NS & - & NS & NS & - \\
\hline $\mathrm{I} \times \mathrm{P}$ & & & NS & NS & NS & NS & NS & $* * *$ \\
\hline $\mathrm{M} \times \mathrm{P}$ & & & NS & NS & - & $* *$ & $* * *$ & - \\
\hline $\mathrm{I} \times \mathrm{M} \times \mathrm{P}$ & & & NS & NS & - & $* *$ & NS & - \\
\hline
\end{tabular}

${ }^{\text {a }}$ By analysis of variance; $* * * P<0.001 ; * * P<0.01$; NS, not significant. 


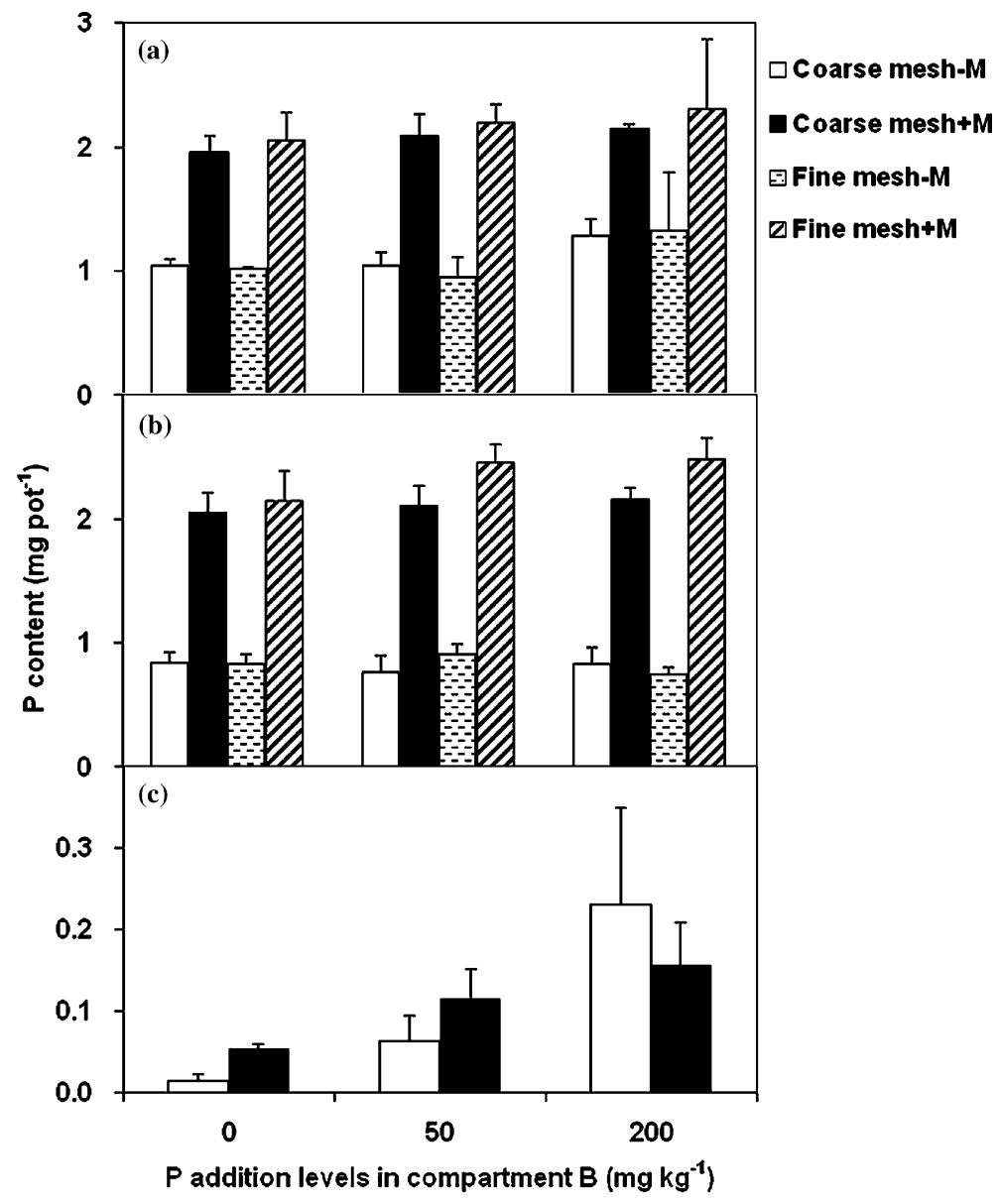

Figure 3. P content of shoots (a), roots in compartment A (b) and compartment B (c) of medic plants under different compartmentation and $\mathrm{P}$ application treatments. $-\mathrm{M}$ and $+\mathrm{M}$ represent non-inoculation treatment and inoculation with mycorrhizal fungus $G$. intraradices. By analysis of variance, inoculation was highly significant for both shoot and root in compartment $\mathrm{A}$ $(P<0.001)$. Shoot $\mathrm{P}$ content was also significantly influenced by $\mathrm{P}$ addition in compartment $\mathrm{B}(P<0.05)$, and $\mathrm{P}$ content of root in compartment A also significantly influenced by mesh size of the nylon net $(P<0.001)$, and the interaction of inoculation with mesh size $(P<0.01)$ and inoculation with $\mathrm{P}$ addition $(P<0.05)$. $\mathrm{P}$ content of root in compartment $\mathrm{B}$ was only influenced by $\mathrm{P}$ addition $(P<0.001)$

In contrast, $G$. intraradices significantly increased $\mathrm{U}$ content in $\mathrm{C}_{\mathrm{A}}$ roots $(P<0.001)$, furthermore the root $\mathrm{U}$ contents were significantly lower with the coarse than with the fine mesh $(P<0.001)$ (Figure $4 \mathrm{~b})$. On the other hand, $\mathrm{U}$ Content in $\mathrm{C}_{\mathrm{B}}$ roots increased with increasing $\mathrm{P}$ levels $(P<0.05)$ (Figure 4c) in accordance with $P$ effects on root growth. Interactions were detected between inoculation and $\mathrm{P}$ application treatments $(P<0.05)$.

Medic plants partitioned less than $15 \%$ of the total U uptake from roots to shoots (Figure 5) and non-mycorrhizal controls had much higher shoot to root ratios than the corresponding inoc- ulated treatments $(P<0.001)$. Compared with fine mesh compartmentation, the $\mathrm{U}$ partitioning to shoots was higher in the coarse mesh treatments with root accessing the $\mathrm{C}_{\mathrm{B}}$ soil than in the corresponding fine mesh treatment $(P<0.001)$. This was most consistent in inoculated plants.

\section{Discussion}

This in vivo study supports the findings from previous studies (Chen et al., 2005; Rufyikiri et al. 2003, 2004b;) and indicates the potential role of AM fungi in phytostabilization of $U$ contaminated 


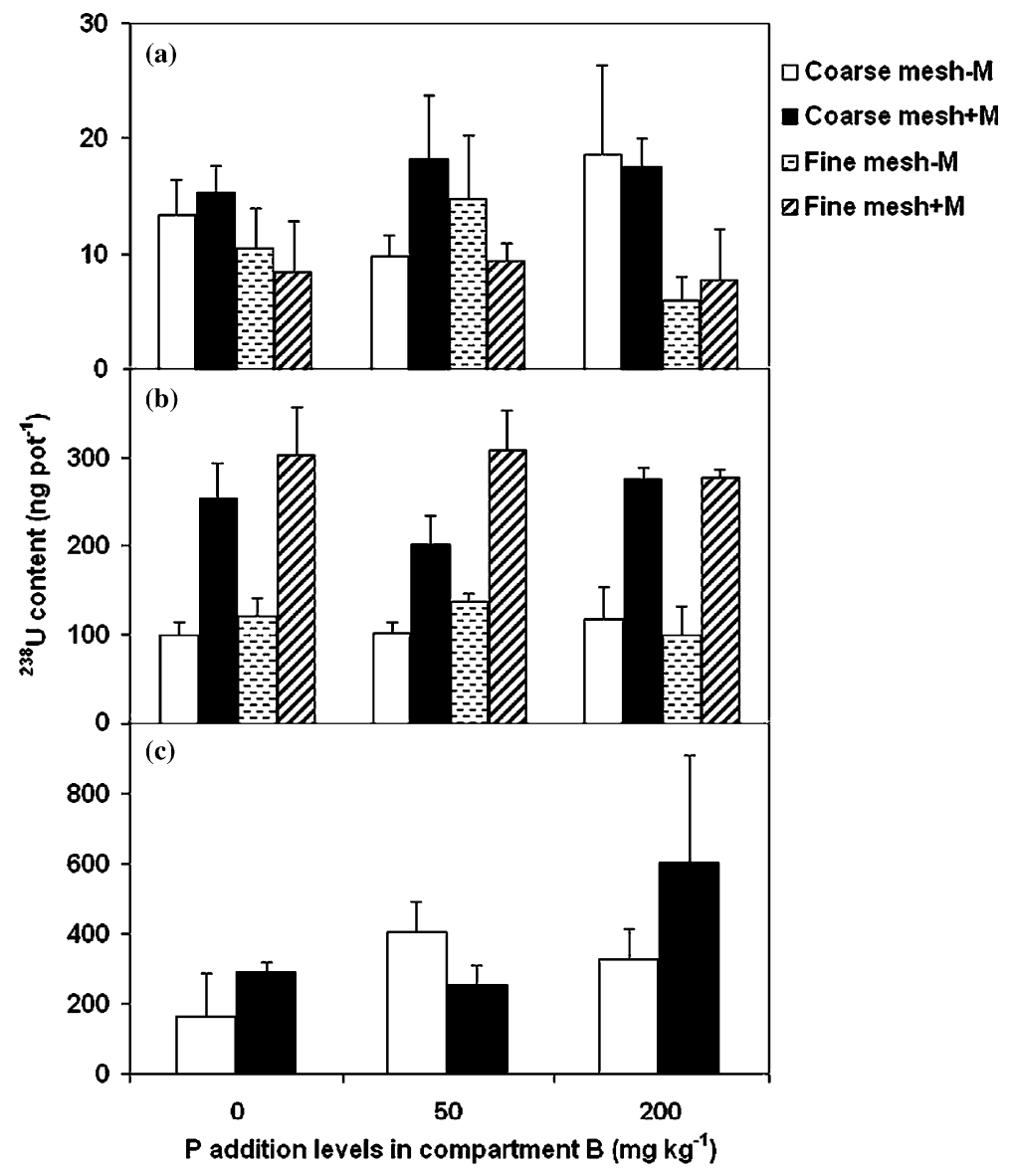

Figure 4. ${ }^{238} \mathrm{U}$ content of shoots (a), roots in compartment A (b) and compartment B (c) of medic plants under different compartmentation and $\mathrm{P}$ application treatments. $-\mathrm{M}$ and $+\mathrm{M}$ represent non-inoculation treatment and inoculation with mycorrhizal fungus G. intraradices. By analysis of variance, mesh size was highly significant for both shoot and root in compartment $\mathrm{A}$ $(P<0.001)$; Inoculation was only highly significant $(P<0.001)$ for root in compartment A; Interaction of inoculation with mesh size was significant $(P<0.05)$ and that of mesh size with $\mathrm{P}$ addition was highly significant $(P<0.01)$ for both shoot and root in compartment $\mathrm{A}$. The interactions among inoculation, mesh size and $\mathrm{P}$ addition were also significant $(P<0.05)$ for shoot. $\mathrm{U}$ content of root in compartment $\mathrm{B}$ was influenced by $\mathrm{P}$ addition $(P<0.05)$, and the interaction of inoculation with $\mathrm{P}$ addition $(P<0.05)$.

environments. However, the compartmented cultivation system used in the present study has obvious advantages (Smith et al., 2003): $C_{B}$ occupied only $5 \%$ volume of $\mathrm{C}_{\mathrm{A}}$ and the system allows investigations on elemental uptake and translocation by mycorrhiza or hyphae under nearly natural conditions without serious interference from spatial restriction of root growth.

If plant shoots are not taken into account, the compartmented system used here is in principle similar to the model system used by Rufyikiri et al. (2003). The influence of mycorrhizas on U uptake and accumulation by roots was rather similar in the two systems: $U$ concentrations and contents of roots from $\mathrm{C}_{\mathrm{A}}$ were significantly higher in G. intraradices-inoculated plants than in the corresponding non-inoculated controls. Rufyikiri et al. (2003) demonstrated that U concentration in external hyphae was 5.5 and 9.6-fold higher than those in mycorrhizal and non-mycorrhizal roots respectively. External hyphae had higher U flux rates than host roots, but internal hyphae may contribute largely to $\mathrm{U}$ immobilization in the mycorrhiza. In the present work, there were also data to show that when only hyphae could access $U$ in $C_{B}$, $U$ concentration and contents of roots in $\mathrm{C}_{\mathrm{A}}$ were higher than when roots could access $C_{B}$. 


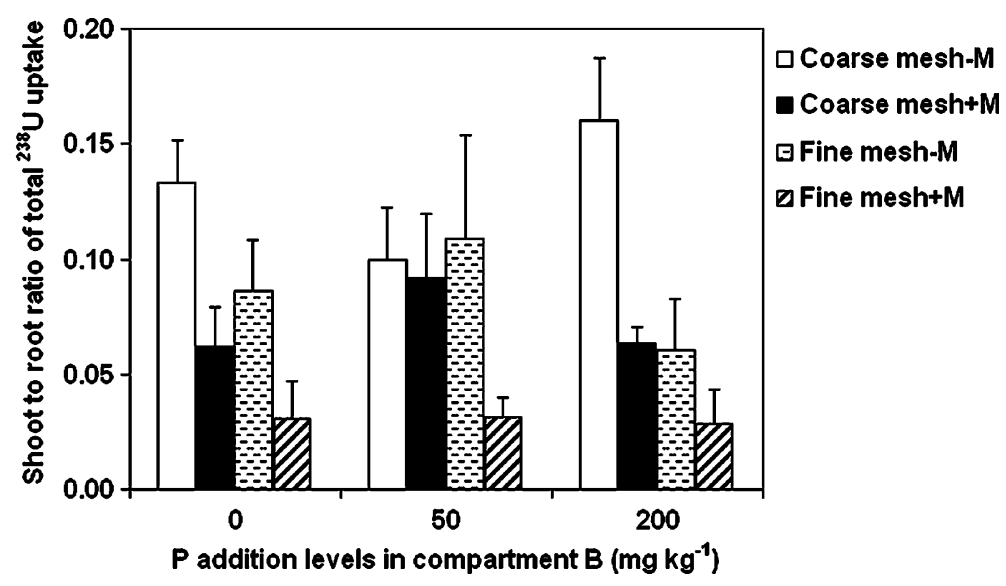

Figure 5. Shoot to root (from compartment A) ratio of total uranium uptake by medic plants as influenced by different compartmentation and $\mathrm{P}$ addition treatments. $-\mathrm{M}$ and $+\mathrm{M}$ represent non-inoculation treatment and inoculation with mycorrhizal fungus G. intraradices. By analysis of variance, inoculation and mesh size $(P<0.001)$, and the interactions among inoculation, mesh size and $\mathrm{P}$ addition $(P<0.01)$ were highly significant.

No large amount of $\mathrm{U}$ was translocated to the plant shoots, and $\mathrm{U}$ immobilization in roots was greatly enhanced by mycorrhizal colonization. This was shown by lower shoot U concentrations in inoculated plants and by shoot to root ratios of total U uptake. It was furthermore noticeable that more $U$ had been partitioned to plant shoots when $650 \mu \mathrm{m}$ net was used than when $25 \mu \mathrm{m}$ net was used. In other words, U uptake through the root pathway could be more easily translocated to plant shoots than $U$ taken up though the fungal pathway. The mycorrhizamediated U uptake was most likely immobilized in root-internal fungal structures as suggested by the observed accumulation of $U$ in fungal vesicles of mycorrhizal Cynodon dactylon roots (Weiersbye et al., 1999).

Separation of the two compartments by different mesh sizes influenced root colonization and fungal growth. Where roots could not grow into $C_{B}$ to take up $P$, root colonization in $C_{A}$ was significantly higher than where roots could grow into $C_{B}$, and at the same time hyphal length density in $C_{B}$ was higher. It seems that plants were regulating mycorrhizal development according to accessibility/availability of $\mathrm{P}$ sources. With low P supply, host plants would rely more on mycorrhizal fungi for $\mathrm{P}$ acquisition. When only hyphae could grow into $\mathrm{C}_{\mathrm{B}}, \mathrm{P}$ contents in roots in $\mathrm{C}_{\mathrm{A}}$ were significantly higher than when there was root access to $\mathrm{P}$ in $\mathrm{C}_{\mathrm{B}}$. This indicates that hyphae could not only efficiently take up P (Li et al., 1991; Rufyikiri et al., 2004a), but also efficiently transfer $\mathrm{P}$ to host plants (Viereck et al., 2004).

It was noticeable that due to the low soil $\mathrm{P}$ supply, the shoot $\mathrm{P}$ concentrations of medic plants were generally quite low $\left(<1 \mathrm{mg} \mathrm{g}^{-1}\right)$ even for inoculated plants (by obvious dilution effects). Despite that no typical symptoms of $\mathrm{P}$ deficiency were found among inoculated pots, the potential effects of plant $\mathrm{P}$ nutrition status on $U$ accumulation could not be neglected. It is documented that plant uptake of $\mathrm{U}$ is affected by various factors, such as soil properties (Shahandeh and Hossner, 2002) and uraniumphosphorus interactions (Ebbs et al., 1998; Jerden Jr. et al., 2003). When P was present at high concentrations, complexes between $\mathrm{U}$ and $\mathrm{P}$ could most likely be formed in the soil. However, $\mathrm{U}$ and $\mathrm{P}$ may also interact during transportation processes within the plants. Though the experimental data from present study indicated that $\mathrm{P}$ addition in $\mathrm{C}_{\mathrm{B}}$ did not influence fungal development or $\mathrm{U}$ accumulation by plants, plant $\mathrm{P}$ nutrition status could still indirectly influence $U$ accumulation by influencing plant growth (root physiological activities) and the development of mycorrhizal symbiosis. Thus there is a need to conduct further investigations on $\mathrm{U}-\mathrm{P}$ interactions both in soil and plants as mediated by mycorrhizal associations. 
To understand the underlying mechanisms is no doubt important for proper manipulation of the combination of plants with associated microbes or fertilization strategies for maximizing the efficiency of phytoremediation.

In conclusion, this study further demonstrated that AM may play an important role in plant adaptation to $\mathrm{U}$ contaminated soils by not only improving plant $\mathrm{P}$ acquisition ability, but also enhancing $U$ immobilization by roots, thus reducing $\mathrm{U}$ partitioning into plant shoots and environmental risks. There is no doubt that AM can play a role in future phytoremediation of $U$ contaminated environments.

\section{Acknowledgements}

This work was financially supported by the EU-MYRRH project contract-CT-2000-00014, Use of mycorrhizal fungi for the phytostabilization of radio-contaminated environments'. BD Chen also gratefully acknowledges the continuous help and technical support from Anne Olsen and Annette Olsen throughout the experiments. Y-G Zhu is supported by Natural Science Foundation of China (40225002) and the "Hundred Talent Program" of the Chinese Academy of Sciences.

\section{References}

Bunzl K, Kretner R, Schramel P, Szeles M and Winkler R 1995 Speciation of ${ }^{238} \mathrm{U},{ }^{226} \mathrm{Ra},{ }^{210} \mathrm{~Pb},{ }^{228} \mathrm{Ra}$, and stable $\mathrm{Pb}$ in the soil near an exhaust ventilating shaft of a uranium mine. Geoderma 67, 45-53.

Chen B D, Christie P and Li X L 2001 A modified glass bead compartment cultivation system for studies on nutrient uptake by arbuscular mycorrhiza. Chemosphere 42, 185-192.

Chen B D, Jakobsen I, Roos P, Borggaard O K and Zhu Y G 2005 Mycorrhiza and root hairs enhance acquisition of phosphorus and uranium from phosphate rock but mycorrhiza decreases root to shoot uranium transfer. New Phytol. $165,591-598$

Campbell M D and Biddle K T 1977 Frontier areas and exploration techniques. Frontier uranium exploration in the south-central United States. In Geology of Alternate Energy Resources. . Ed. M D Campbell. pp. 3-44. Houston Geological society, Houston, Texas.

Ciavatta L, Ferri D, Grenthe I and Salvatore F 1981 The first acidification step of the tris(carbonate)dioxourantantate(VI) ion, $\mathrm{UO}_{2}\left(\mathrm{CO}_{3}\right)_{3}{ }^{4-}$. J. Inorg. Chem. 20, 463-467.

Duff M C and Amrhein C 1996 Uranium (VI) adsorption on goethite and soil in soil carbonate solutions. Soil Sci. Soc. Am. J. 60, 1393-1400.
Dushenkov S 2003 Trends in phytoremediation of radionuclides. Plant Soil 249, 167-175.

Ebbs S D, Brady D J and Kochian L V 1998 Role of uranium speciation in the uptake and translocation of uranium by plants. J. Exp. Bot. 49, 1183-1190.

Fellows R J, Ainsworth C C, Driver C J and Catoldo D A 1998 Dynamics and transformation of radionuclides in soils and ecosystem health. In Soil Chemistry and Ecosystem Health. Eds. WI Madison. pp. 85-131. Soil Sci. Soc. Am., USA.

Francis A J and Dodge C J 1998 Remediation of soils and wastes contaminated with uranium and toxic metals. Environ. Sci. Technol. 32, 3993-3998.

GenStat Committee 2002 The guide to GenStat (release 6.1). Part 1: Syntax and data management. Payne RW, VSN International, Hemel Hempstead, UK.

Grenthe I, Fuger J, Konings R, Lemire RJ, Muller AB, Nguyen-Trung C and Wanner J 1992 The Chemical Thermodynamics of Uranium. Elsevier, New York.

Huang J W, Blaylock M J, Kapulnik Y and Ensley B D 1998 Phytoremediation of uranium- contaminated soils: role of organic acids in triggering uranium hyperaccumulation in plants. Environ. Sci. Technol. 32, 2004-2008.

Jakobsen I, Abbott L K and Robson A D 1992 External hyphae of vesicular-arbuscular mycorrhizal fungi associated with Trifolium subterranum L. (1) Spread of hyphae and phosphorus inflow into roots. New Phytol. 120, 371-380.

Jakobsen I and Nielsen N E 1983 Vesicular arbuscular mycorrhiza in field grown crops I. Mycorrhizal infection in cereals and peas at various times and soil depths. New Phytol 93, 401-413.

Jerden J L Jr, Sinha A K and Zelazny L 2003 Natural immobilization of uranium by phosphate mineralization in an oxidizing saprolite-soil profile: chemical weathering of the Coles Hill uranium deposit, Virginia. Chem. Geol. 199, 129-157.

Joner E J, Briones R and Leyval C 2000 Metal-binding capacity of arbuscular mycorrhizal mycelium. Plant Soil 226, 227-234.

Langmuir D 1978 Uranium solution-mineral equilibria at low temperatures with applications to sedimentary ore deposits. Geoch. Cosmoch. Acta 42, 547-569.

Leyval C, Joner E J, del Val C and Haselwandter K 2002 Potential of arbuscular mycorrhizal fungi for bioremediation. In Mycorrhizal Technology in Agriculture. Eds. S Gianinazzi, H Schüepp, J M Barea \& K Haselwandter. pp. 175-186. Birkhäuser Verlag, Basel Switzerland.

Li X L, Geoege E and Marschner H 1991 Extension of the phosphorus depletion zone in VAM white clover in a calcareous soil. Plant soil 136, 41-48.

Mortvedt J J 1994 Plant and soil relationships of uranium and thorium decay series radionuclides - a review. J Environ. Qual. 23, 643-650.

Pearson J N and Jakobsen I 1993 The relative contribution of hyphae and roots to phosphorus uptake by arbuscular mycorrhizal plants measured by dual labelling with ${ }^{32} \mathrm{P}$ and ${ }^{33}$ P. New Phytol. 124, 489-494.

Phillips J M and Hayman D S 1970 Improved procedures for clearing and staining parasitic and vesicular-arbuscular mycorrhizal fungi for rapid assessment of infection. Trans. Br. Mycol. Soc. 55, 158-161.

Rufyikiri G, Thiry Y and Declerck S 2003 Contribution of hyphae and roots to uranium uptake and translocation by arbuscular mycorrhizal carrot roots under root-organ culture conditions. New Phytol. 158, 391-399. 
Rufyikiri G, Thiry Y, Wang L, Delvaux B and Declerck S 2002 Uranium uptake and translocation by the arbuscular mycorrhizal fungus, Glomus intraradices, under root-organ culture conditions. New Phytol. 156, 275-281.

Rufyikiri G, Declerck S and Thiry Y 2004a Comparison of ${ }^{233} \mathrm{U}$ and ${ }^{33} \mathrm{P}$ uptake and translocation by the arbuscular mycorrhizal fungus Glomus intraradices in root organ culture conditions. Mycorrhiza 14, 203-207.

Rufyikiri G, Huysmans L, Wannijn J, Van Hees M, Leyval C and Jakobsen I 2004b Arbuscular mycorrhizal fungi can decrease the uptake of uranium by subterranean clover grown at high levels of uranium in soil. Environ. Pollut. 130, 427-436.

Saric M R, Stojanovic M and Babic M 1995 Uranium in plant species grown on natural barren soil. J. Plant Nutri. 18, $1509-1518$.

Shahandeh H and Hossner L R 2002 Enhancement of uranium phytoaccumulation from contaminated soils. Soil Sci. 167 269-280.

Shahandeh H, Lee J H, Hossner L R and Loeppert R H 2001 Bioavailability of uranium and plutonium to plants in soil-water systems and the potential of phytoremediation. In Trace Elements in the Rhizosphere. Eds. G R Gobran., W W Wenzel. \& E Lombi. pp. 93-124. CRC Press LLC, London, UK.

Sheppard M I and Thibault D H 1984 Natural uranium concentrations of native plants over a low-grade ore body. Can. J. Bot. 62, 1069-1075.

Sheppard M I and Thibault D H 1992 Desorption and extraction of selected heavy metals from soils. Soil Sci. Soc. Am. J. 56, 415-423.

Smith S E and Barker S J 2002 Plant phosphate transporter genes help harness the nutritional benefits of arbuscular mycorrhizal symbiosis. Trends Plant Sci. 7, 189-190.
Smith S E and Read D J 1997 Mycorrhizal Symbiosis. $2^{\text {nd }}$ edn Academic Press, London, UK.

Smith S E and Smith F A 1990 Structure and function of the interfaces in biotrophic symbioses as they relate to nutrient transport. New Phytol. 114, 1-38.

Smith S E, Smith F A and Jakobsen I 2003 Mycorrhizal fungi can dominate phosphate supply to plants irrespective of growth responses. Plant Physiol. 133, 16-20.

Viereck N, Hansen P E and Jakobsen I 2004 Phosphate pool dynamics in the arbuscular mycorrhizal fungus Glomus intraradices studied by in vivo ${ }^{31} \mathrm{P}$ NMR spectroscopy. New Phytol. 162, 783-794.

Weiersbye I M, Straker C J and Przybylowicz W J 1999 MicroPIXE mapping of elemental distribution in arbuscular mycorrhizal roots of the grass, Cynodon dactylon, from gold and uranium mine tailings. Nucl. Instru. Meth. Phys. Res. B 158, 335-343.

Whiting S N, Reeves R D, Richards D, Johnson M S, Cooke J A, Malaisse F, Paton A, Smith J A C, Angle J S, Chaney R L, Ginocchio R, Jaffré T, Johns R, McIntyre T, Purvis O W, Salt D E, Schat H, Zhao F J and Baker A J M 2004 Research priorities for conservation of metallophyte biodiversity and their potential for restoration and site remediation. Res. Ecol. $12,106-116$.

Xu L C, Wang Y X, Liu J W, Lu X S, Liu Y C and Liu X Y 2002 Radioactive contamiantion of the environment as a result of uranium production: a case study at the abandoned Lincang uranium mine, Yunnan Province, China. Sci China (B) $45,11-19$.

Zhu Y-G and Shaw G 2000 Soil contamination with radionuclides and potential remediation. Chemosphere 41, 121-128.

Section editor: F.J. Zhao 